OPEN ACCESS

Edited by:

Nino Antadze,

University of Prince Edward

Island, Canada

Reviewed by:

Forrest Clingerman,

Ohio Northern University,

United States

Karen Morrow,

Swansea University, United Kingdom

*Correspondence:

Alexander Hall

a.f.hall@bham.ac.uk

Specialty section

This article was submitted to Climate Risk Management,

a section of the journal

Frontiers in Climate

Received: 03 November 2021 Accepted: 08 February 2022 Published: 03 March 2022

Citation:

Hall A (2022) That Fine Rain That

Soaks You Through. Exploring the Role of Weather Lore, Cultural Identity, and Community Memory in Shaping Attitudes to Climate Change. Front. Clim. 4:808609.

doi: 10.3389/fclim.2022.808609

\section{That Fine Rain That Soaks You Through. Exploring the Role of Weather Lore, Cultural Identity, and Community Memory in Shaping Attitudes to Climate Change}

\author{
Alexander Hall* \\ Institute for STEM in Culture and Society, University of Birmingham, Birmingham, United Kingdom
}

As the limitations of climate change communication, which focusses on the dissemination of scientific knowledge has become apparent, climate studies scholars have called for richer, less reductive approaches. This includes adopting more emotive language, which is sensitive to the myriad ways communities understand and know their own environ and climate. While on the surface, the recent emotive turn of popular discourse on anthropogenic climate change seems to heed this call, the communication approaches most commonly associated with these developments are limited in their ability to reach diverse communities. This article attempts to address this gap and contribute to affecting action in a manner which is both proportionate with the immediate climate risk, but also successful in engaging a range of groups within the community. Exploring the links between weather lore, cultural identity, and memory in shaping individual perceptions of climate risks, the article asks how such identities, both at the community and individual level, might have informed indifference or inaction with regards to climate change. Adopting a style that situates the author within the narrative, this essay uses Manchester, England and its popular reputation as 'the rainy city' to explore these themes. Charting the history of the popularization of the meteorological myth that Manchester receives excessive amounts of rainfall, the article exposes how this folklore is bound up in regional cultural identity and civic pride, first as "Cottonopolis" at the vanguard of the Industrial Revolution, and then in the city's post-industrial rebranding as a place known for music, comedy, and sporting successes. In drawing these threads through community, familial and individual narratives, the article concludes by outlining how we might better utilize affection and cultural identification with local environments and weather to promote future behavior change.

Keywords: cultural identify, local climate, climate communication, Manchester, history of meteorology 


\section{INTRODUCTION}

In recent decades, climate studies scholars from across the humanities have explored the abstract nature and plurality of definitions the term "climate" holds for different communities across time and space (Nerlich et al., 2010; Fleming and Jankovic, 2011; Hulme, 2011a). Historians have argued that climate's incorporation into a largely techno-scientific framework during the twentieth century has somewhat obscured the term's historical fluidity as a concept (Fleming and Jankovic, 2011). In revisiting the "ancient vocabulary" of climate, such work urges us to broaden our interrogation of climate-and in turn climate change-beyond the reductive lens of the atmospheric sciences, to explore how climate is an integral component of both individual and community identities. As the historian of science, James Fleming argues:

\begin{abstract}
"Collectively, climate shapes life in specific places in fundamental and dramatic ways; it is woven into the fabric of the human past and future; both the experience and knowledge of climate is shaped by and enframed in our lifestyles, our seasonality, our clothing and housing, our aspirations and our tragedies. Climate involves themes of dominant empires, colonial pride and pioneer mentalities; popular, religious and racial sentiments; imposed and imported ideologies; and resilience to extreme conditions of flood and drought as embodied in agricultural and technological practices. Climate is both intimate and universal, involving local experiences of global change (Fleming, 2015)."
\end{abstract}

Reimagining pre-twentieth-first century historical understandings of climate and embracing the elusive nature of the term is more than just an esoteric academic exercise. Recent scholarship has demonstrated that historical research at the climate-society interface can play an integral role in climate change adaptation (e.g., Adamson et al., 2018). Providing insight into social processes in specific environs and communities across long time-periods is a crucial component of understanding how to affect change today.

A wide range of historical studies on the climate-society interface have highlighted the limitations of contemporary popular discourse on climate change and climate change adaptation, from work in historical climatology (Pfister, 2010) to anthropological approaches focused on traditional ecological knowledge of indigenous populations (e.g., Lefale, 2010; Royer, 2018). Influenced by their own specific historical trajectories, how each community understand climate and climate change often manifests in plural, divergent and sometimes contradictory ways. Furthermore, each community and individual within it has inequitable access to climate science and climate adaptation measures (Schlosberg and Collins, 2014). The challenge for those working in science communication trying to promote the necessary adaptive change, whether in mitigating emissions or building climate resilience, is further exacerbated by valid issues of trust in both political and scientific institutions from some of the most marginalized in society. ${ }^{1}$ In facing such challenges, there

${ }^{1}$ There are ample examples from the history of science and medicine of cases where scientists, governments, and corporations knowingly lied to or exploited is a need for research that alongside policy, infrastructural, and community level analysis begins to explore and help us better understand the complex social processes that inform individual perceptions and actions with regard to climate change.

Over the past three decades, the overwhelming majority of science communication on climate change has operated in a persuasive mode. This has involved focussing on communicating the relatively complex atmospheric science that informs our understanding of anthropogenic climate change, with a view to educating wider society to enact the necessary change. However, such a deficit model approach, which presumes increased knowledge of a scientific subject, correlates with acceptance, trust and action rarely holds up to empirical scrutiny (Simis et al., 2016; Suldovsky, 2017). As the scale and urgency of the adaptive responses climate change requires have continued to increase, somewhat belatedly, climate studies scholars have begun shifting from a purely educational and persuasive mode to a more active model, which aims to empower communities to enact adaptive change and to lobby government and corporate authorities for largescale systemic changes (Green, 2020).

As someone who considers himself an "active historian" and a science communication practitioner who spends a lot of time volunteering on various public engagement initiatives, this shift in emphasis has been something I personally have welcomed. ${ }^{2}$ However, as I reflected on what a more participatory approach to climate change communication might look like, I realized that despite my own academic understanding of the limitations of the deficit model-from science festivals to stand-up comedy nights-my own practice largely engaged with individuals for whom science was already a central part of their social or cultural identity (Elsdon-Baker and Lightman, 2020). In attempting to address this imbalance by co-creating more salient interventions and activities that would reach more diverse local communities, I realized that not just our communicative tools, but also our empirical understanding of how groups in society understand and interact with their environment, are hugely lacking.

Historians, along with other colleagues across the social sciences and humanities, are well-situated to address this lacuna. For example, exploring, how over time, local weather and climatic conditions have been incorporated via linguistic devices such as dialect, narrative form, and metaphor into cultural and civic identities (Nerlich et al., 2010). Without such baseline research ${ }^{3}$, we are in danger of (somewhat paradoxically)

marginalised communities. For examples focussed on two different marginalised communities in North America, see Reverby, 2012; van Horssen, 2016.

${ }^{2}$ The ActiveHistory.ca website defines Active History as "history that listens and is responsive; history that will make a tangible difference in people's lives; history that makes an intervention and is transformative to both practitioners and communities". Available online at: http://activehistory.ca/about/ (last accessed October 7, 2021).

${ }^{3}$ This gap in the baseline understanding of how cultural and social dimensions mediate the relationship between people and their environ is somewhat analogous to the problem posed by Shifting Baseline Theory. First outlined by fisheries scientist Daniel Pauly (Pauly, 1995) the concept describes how in many areas of ecology, scientists work from a shifted baseline and underestimate what a healthy ecosystem originally looked like. More recently applied to areas such as political ecology (e.g., Ringer et al., 2018), for those interested in understanding the climatesociety interface this framework and literature may prove fruitful, particularly in 
over-estimating the public's desire to understand complex atmospheric and geo-political processes, while at the same time underestimating their capacity to tacitly know-both in physical and cultural terms-their own environment and how it is changing. That is not to say that we must ever lose sight of the empirical, but rather that perhaps too much climate scholarship to date has focused on the empirical to the deficit of our understanding of the social, familial, and everyday ways that people know climate.

Adding to growing literature addressing this gap (e.g., Holzhausen and Grecksch, 2021) this essay demonstrates how community and individual identity is informed by the weather. Using the case study of Manchester, England, and its meteorologically inaccurate reputation as the rainy city, I demonstrate the importance of contingent historical developments over and above rational meteorological statistics. For, if we are to inform and affect large-scale societal change, we first have to understand better how individuals and communities conceive their physical environ, their climate, day to day weather, extreme weather events, and the links between these systems (Strauss and Orlove, 2003; Ingold, 2011). In turn, we can then begin to better understand how these factors influence, are influenced by, and are incorporated into individual and community identity, worldviews, and everyday routine activities.

\section{MATERIALS AND METHODS}

In keeping with the aims and approaches of this special edition on the "Affective Dimensions of Climate Risk", in this essay I adopt an autoethnographic approach, which situates my own experience within the wider cultural and scientific history outlined. ${ }^{4}$ The combining of scholarly analysis with reflective prose introduces heteroglossia to the narrative presented, reflecting the plurality of understandings and ascribed meanings that climate itself can take across diverse communities. Further, by adopting this form, I hope to encourage other academics to take more seriously the role of narrative and storytelling, not only in public engagement activities, but also in our own work communicating with each other. I hope that this creative approach, which combines the systematic and the poetic, is both compelling and analytically productive.

\section{Shaping Individual Perceptions of Climate}

Over the last decade geographers (e.g., Hulme, 2012), historians (e.g., Hall and Endfield, 2016), and other humanities scholars (e.g., Barnes and Dove, 2015) have made significant contributions to our understanding of how both communities and individuals construct their perceptions of climate and climate change. This scholarship has begun to unpack how individual's perceptions of climate and climate change interconnect with their perceptions of the weather and their environment, which in turn are shaped by a complex web of cultural, political, and social factors

historical climatological research that seeks to incorporate documentary evidence into our conceptions of past climates and societies.

${ }^{4}$ For an introduction to autoethnography and associated qualitative approaches to research, see Adams et al., 2015.
(Carvalho, 2007; Myrick and Comfort, 2019). Alongside this work, sociological and social psychological research has also shown how social identity and "in-group" pressures play an important role in individual behavior and community-level actions in response to climate change and other environmental issues (Barth et al., 2021).

In summarizing the growing literature that explores the climate-society interface, Adamson et al. (2018) state that, "[a] focus on weather-worlds can provide a theoretical lens to illuminate the cultural losses likely to result from a change of climate by fully exploring the cultural attachment that people have to weather and environmental variability in a particular place" (Adamson et al., 2018, p. 200). While being wary of deterministic narratives that reduce complexity and limit agency, they identify three main ways that historians can productively intervene in adaptation studies: “particularizing' adaptation, analysis of institutional path dependency and memory, and historicizing the concept of adaptation" itself (Adamson et al., 2018, p. 199). In outlining one case study about the city of Manchester and the history of its association with rain, this article attempts to "thicken" our understanding of how industrial and post-industrial communities have adapted and demonstrates that in this urban setting path dependency was informed as much by regional economics, civic narratives, and regional identity as it was by climatological realities.

My approach draws on a variety of ethno-meteorological traditions. The earliest of which were anthropological studies on the understanding of weather and climate across cultures, largely focused on recording weather folklore (e.g., La Barre, 1942). A more recent resurgence in academic interest in ethnometeorology has centered on disentangling observational and empirical understandings of a community's weather and environment from the folkloric and mythic narratives within which they are often bound (Orlove et al., 2000; Anandaraja et al., 2008). Much of this work has a reductive focus, seeking to extract information, knowledge, and data useful to contemporary science. Largely situated within wider scholarship on traditional ecological knowledge, this scholarship has most often focused on indigenous populations in settleroccupied territories. By contrast, attention on the cultural dimensions of weather in urban and western settings has instead focused on the social dimensions of lay knowledge about the weather, with prominent histories written on areas such as the amateur/professional divide in meteorology (Golinski, 2010) and the role of "citizen science" in early climatological activities (Hall, 2015). At the same time, non-historical studies on cultural dimensions of weather, both those exploring traditional ecological knowledge and more recent scientific modes, have overwhelmingly treated ethno-meteorological knowledge as something historical and static, to be analyzed for often utilitarian purposes. With the following case study, I hope to highlight the validity of turning the original anthropological lens of ethnometeorology on all societies, time-periods, and contexts; showing that dominant cultural understandings of weather and place-whether accurate rules of thumb, or errant mythscan emerge and become embedded in relatively short spaces of time. 
In thinking about shifting from the abstract aim of exploring how weather shapes cultural identities, to the more pragmatic issue of how research at the climate-society interface can improve climate communication practice, I reflected on my own approaches to research and public engagement. In prior research, exploring how rural communities remember past extreme weather I adopted an approach that centered community co-creation (Hall and Endfield, 2016). This helped to build trust in a community that I parachuted into, and allowed the research design to be reflexive, adapting as participants moved through the project. However, revisiting this work it struck me that I never really reflected upon my own position within the research, which may have limited the study's effectiveness-particularly with regards to reaching more marginalized community members. This turned my thoughts to my own position within wider climate discourse and how

\begin{tabular}{|c|c|c|c|}
\hline Place & $\begin{array}{l}\text { Köppen climate } \\
\text { classification }\end{array}$ & $\begin{array}{l}\text { Average Annual } \\
\text { Rainfall (mm) }\end{array}$ & Days of Rainfall \\
\hline Manchester, UK & $\begin{array}{l}\text { Marine west coast } \\
\text { (Cfb) }\end{array}$ & 807 & 140.4 \\
\hline London, UK & $\begin{array}{l}\text { Marine west coast } \\
(\mathrm{Cfb})\end{array}$ & 584 & 106.5 \\
\hline Cardiff, UK & $\begin{array}{l}\text { Marine west coast } \\
\text { (Cfb) }\end{array}$ & $1,111.7$ & 146.0 \\
\hline UK Average & $\begin{array}{l}\text { Marine west coast } \\
\text { (Cfb) }\end{array}$ & 1,126 & 154.4 \\
\hline Seattle, USA & $\begin{array}{l}\text { Warm-summer } \\
\text { Mediterranean climate } \\
\text { (Csb) }\end{array}$ & 944 & 158 \\
\hline Cherrapunji, India & $\begin{array}{l}\text { Subtropical highland } \\
\text { climate (Cwb) }\end{array}$ & 11,430 & 170.4 \\
\hline
\end{tabular}

FIGURE 1 | A table comparing average rainfall and days of rainfall for Manchester, with selected other locations in the UK and internationally. Sources: UK Met Office and NOAA.

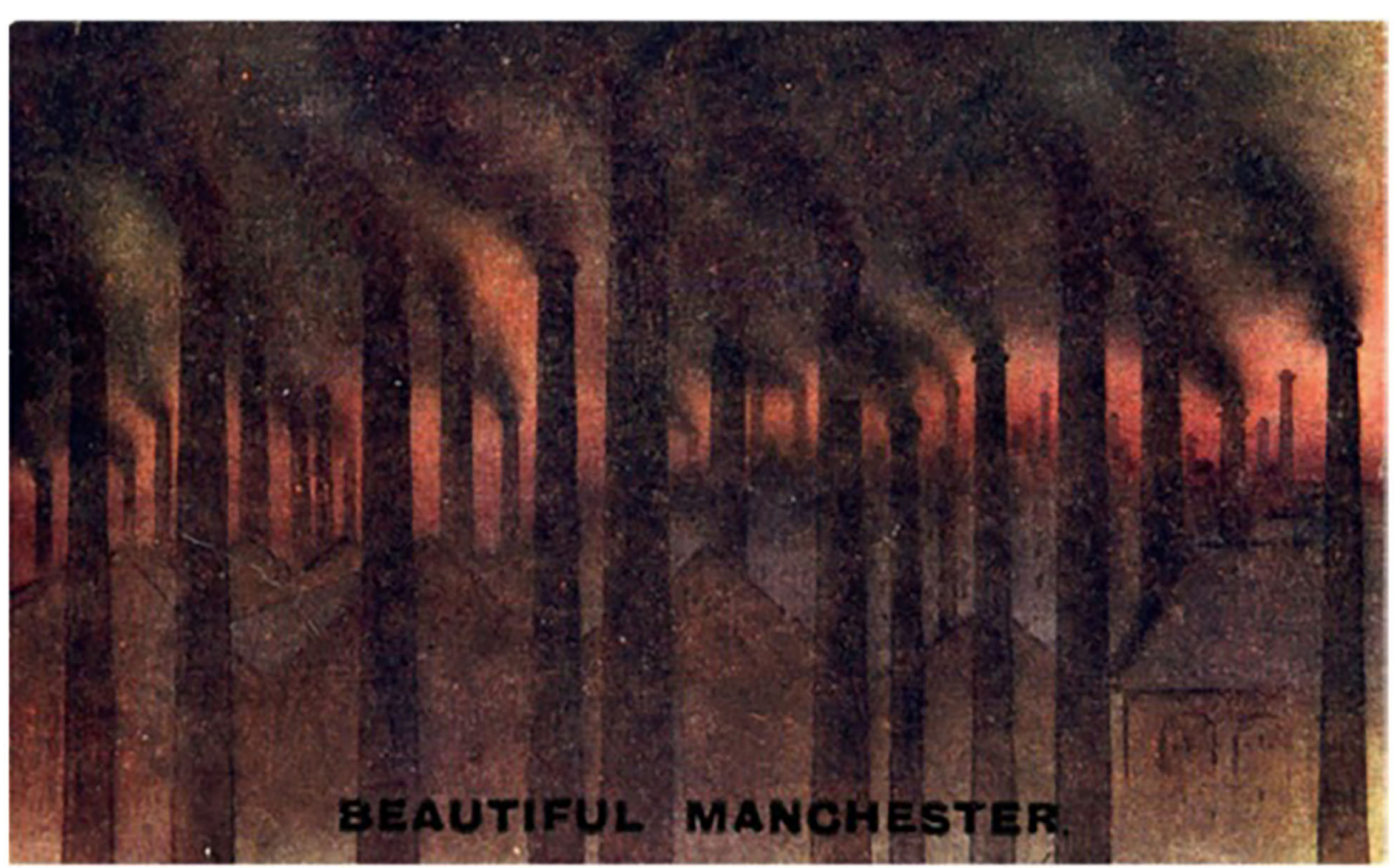

FIGURE 2 | "Beautiful Manchester", humorous postcard, early twentieth century. Source: Mosley S. (2016). Selling the smokeless city: advertising images and smoke abatement in urban-industrial Britain, circa 1840-1960. History Technol. 32, 201-211. doi: 10.1080/07341512.2016.1218956. 
my cultural background and upbringing might have shaped my own affinity with the weather. Hailing from Manchester, wet weather loomed large in my childhood both physically, but also, as I now realize, culturally. So, centring my own experience and attempting to move from the theoretical to the empirical, I first began with a fairly routine historical enquiry. Why, despite all of the meteorological evidence to the contrary, does the city of Manchester in the UK have a popular reputation for being rainy?

\section{RESULTS}

If you're from Manchester, when you travel it is inevitable that three topics will come up when you speak to people. The first is sport and in particular, the city's football teams; the second is pop and rock music; and the third is the rainy climate of the city. As a taxi driver in Cape Town remarked to me in 2014, it always seemed to be raining when he watched his favorite player, Yaya Touré, turn out for Manchester City. While it may be obvious that sporting prowess and artistic success are a source of pride for citizens, it may be more surprising that Mancunians are equally proud of their purportedly inclement weather. Whether being espoused by my dad, proud of his ability to barbeque uninterrupted during a summer rainstorm, or by a taxi driver in far-off climes, this stereotype has always confused me. For as a somewhat self-confessed weather geek, I know that Manchester really is not that wet. In fact, the city in the north-west of England is meteorologically middling when compared to other maritime climates (Figure 1). Despite being below the UK average, for both total rainfall amounts and the number of wet days per year, in popular culture, Manchester is often referred to as the "Rainy City".

\section{Mythmaking: Manchester the Rainy City}

When I first began researching the history of meteorology over 10 years ago, I noticed that it wasn't just me who was interested by the persistence of this popular myth. Generations of British meteorologists had highlighted the erroneous nature of this moniker and attempted to correct the public. In 1946, the Secretary of the Royal Meteorological Society, E. L. Hawke justified his interest in the subject:

\footnotetext{
"An attempt to trace a myth to its source is always interesting, and becomes particularly so when the myth is one that has grown as nation-wide as the reputed raininess of Manchester. This is an important item in the stock-in-trade of every professional humorist, probably ranking next as a time-honored provoker of English laughter to the undesirable qualities of mothers-inlaw... Such notions need only be reiterated often enough to be believed... In books, lectures, and over the radio, meteorologists have repeatedly emphasized that Manchester normally gets little more than the average general rainfall for England, and that out of 100 days 47 ordinarily pass without a measurable shower there. All these efforts to give the libel its quietus are of no avail. So far from dying out, it seems to gather strength and credence as the years go by Hawke (1946).”
}

In this article, Hawke gave an overview of his research into the earliest references to Manchester's pluvial excess. In doing so, he traced the myth back to an 1898 article by the Director of the British Meteorological Office, Robert Henry Scott. Astoundingly even in Scott's late nineteenth-century article, he was already trying to disprove "absurd statements" that in Manchester hardly a day passes without rain. Interestingly, in the 1898 article Scott traced the idea that Manchester is rainy back to a European treatise of 1881, which stated that since Manchester's industrialization, the number of rainy days had increased considerably (Scott, 1898). When Scott's article was discussed at the Royal Meteorological Society, other members contested Scott's attempt to disprove the myth, and anecdotally supported the industrialized increase in rain hypothesis. As one Royal Navy captain argued:

\begin{abstract}
"In manufacturing towns the sun is almost always obscured by smoke haze, and the smoke particles fall back to earth laden with moisture that has condensed on them, thus making the air always feel damp, the streets always grimy, and giving all the sensations of a wet day (Bayard, 1898)."
\end{abstract}

Unfortunately, Scott's article did not provide a reference for the 1881 European treatise, which it blamed for popularizing the hypothesis that Manchester had become rainier since industrialization. Despite extensive searching of meteorological bibliographies, it is still not apparent from which article Scott took this claim. The closest match is an article by the influential German climatologist Wladimir Köppen, published in Hamburg in 1881, however this piece does not refer to Manchester directly (Köppen, 1881).

From the 1790s onwards, Manchester had regularly featured in scholarly discussion of British rainfall measurements. Most notably, originally via the measurement series undertaken by the chemist John Dalton from 1794 to 1819 (Craddock, 1976). In the late-nineteenth century, when Scott was writing, measurements for Manchester where regularly discussed by members of the British Rainfall Organization and the Manchester Literary and Philosophical Society (e.g., Vernon, 1871). When you read the proceedings of these societies, it is evident just how new the idea was that you could even measure and compare rain from place to place.

Discussions about rainfall in Manchester were part of wider conversations that sought to standardize the process of weather measurement and climatological comparison, both to identify regional patterns and urban/rural differences. The emergence of the hypothesis that industrial activity increased rainfall in cities emerged from wider research in which, since the 1850s, scholars had been trying to empirically understand the effects of industrial pollution on the air of urban spaces.

\section{Industrial Pollution and Dampness}

Given its position at the epicenter of nineteenth-century industrialization, Manchester featured heavily in early research on this subject, most famously through the experiments of Scottish chemist Robert Angus Smith, which began in the 1850s (Smith, 1872). Smith eventually identified the phenomenon of acid rain, and his work was a contributing factor in the creation of one of the first pieces of legislation globally that attempted to 
abate industrial pollution, the Alkali Act of 1863 (Reed, 2016). Smith's work supported and fuelled the work of allied social activists, such as the National Smoke Abatement Institution, who campaigned for better conditions in Britain's industrial cities during the second half of the nineteenth century (The National Smoke Abatement Institutions, 1888). ${ }^{5}$

Another factor that influenced Manchester's growing reputation as a wet place was the increased incidence of urban flooding. As the city proliferated during the nineteenth century, many sections of Manchester's rivers were diverted, culverted, or simply covered to make way for new development. With little planning, insufficient drainage and high population densities, deadly floods hit the poorest urban neighborhoods. Following major floods in Manchester and neighboring Salford

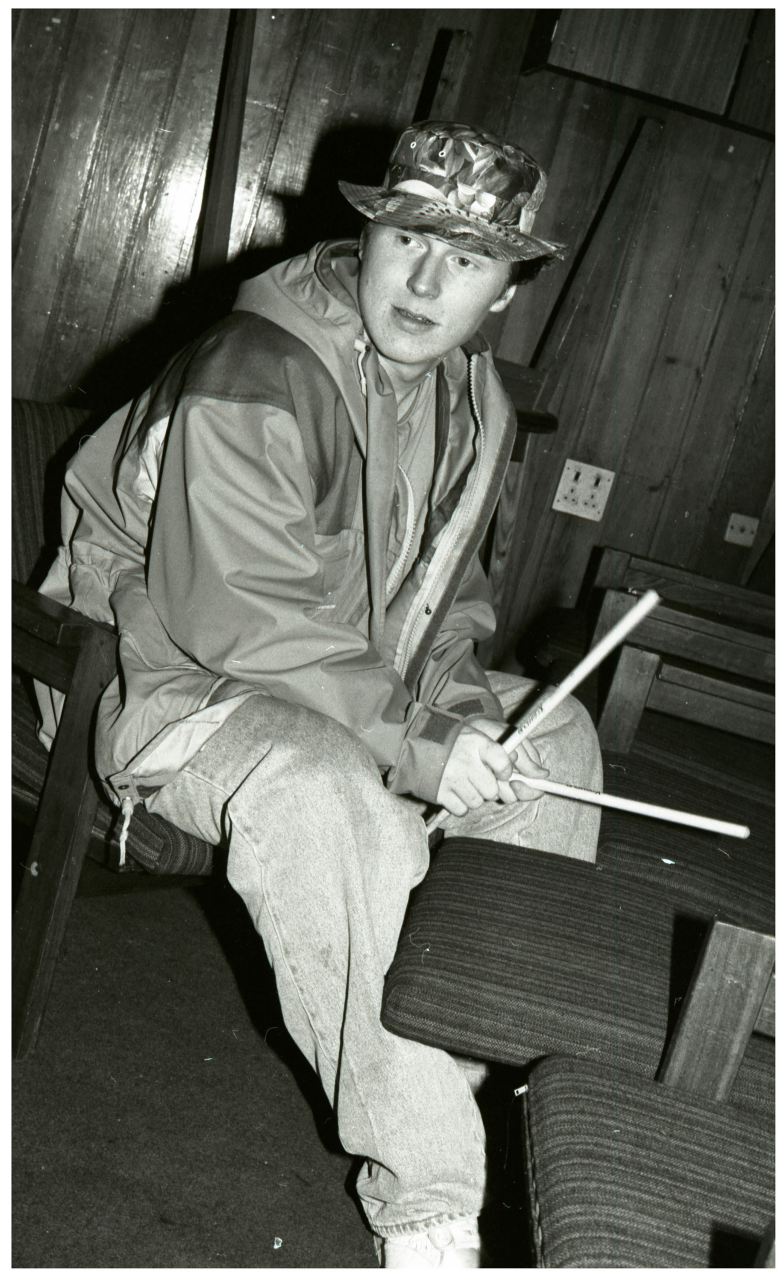

FIGURE 3 | Craig Gill of the Inspiral Carpets wearing a cagoule, circa 1990. (C) Peter Walsh (Museum of Youth Culture).

${ }^{5}$ For more on the research and ideas being promoted by the National Smoke Abatement Institution to middle and upper class citizens of Manchester, see National Smoke Abatement Institution (1887), "Air Pollution: A Series of Lectures, delivered in Manchester during the winter 1886-87" (available at the Meteorological Office Library, Exeter UK) in 1852,1866 , and 1872 , social reformers again campaigned for improvements for the working classes (Platt, 2002).

For civic-minded scientists like Smith and organizations like the National Smoke Abatement Institution, the focus of research and efforts was overwhelmingly on better understanding atmospheric chemistry and local meteorological processes, so that conditions could be improved for urban inhabitants. Yet, industrialists profiting from the factory and mercantile system largely saw such efforts as a threat to their prosperity. These tensions are reflected in popular literature and print culture from the period. For example, in Elizabeth Gaskell's North and South (1855), which explores the personal and environmental upheavals of industrialization, it is in Manchester that the protagonist Margaret learns to tell rainclouds from smoke pollution in the sky (Debrabant, 2010).

The sarcastic and tongue-in-cheek sentiment of the postcard in Figure 2, aligns well with our twenty-first century understanding, which sees all industrial pollution as a wholly negative thing. However, for many who relied on Manchester's nineteenth century industrial landscape for their income and survival, the chimneys of the city were beautiful. While this view may have been more commonly espoused by the mercantile class who directly profited, in spite of the inequitable effects of pollution, for working class citizens the smokestacks of the city were directly tied to your families' wellbeing. Indeed, there was little working-class support for smoke abatement in cities like Manchester until after the Second World War (Mosley S., 2016). With regards to my own family history, it was not until the 1920s that a family member managed to cross this class divide. When, in an event so notable it has echoed down the generations, my greatgrandad crossed the factory floor becoming a supervisor and in doing so irreparably damaging his relationship with his own father.

Generations of historians have attempted to explain why Manchester and the surrounding counties were the epicenter of nineteenth century industrialization. Since at least the 1930s, economic and social historians have endeavored to show that the popular idea that the damp climate was a determining factor in the cotton industries success in North-West England is inaccurate. Despite these attempts, today popular accounts often still rely on such climatic determinism, when there is no discernible correlation between humidity and the historic location of various cotton-processing industries (Ogden, 1927; Jewkes, 1930). Across the twentieth century, the idea that Manchester is a damp place has been repeatedly reinforced by the visual, print and popular culture of the industrial northwest of England (Figures 2, 4). ${ }^{6}$ However, as we reflect on the origins of the idea that the city's damp climate provided the perfect conditions for cotton processing, we can see why

\footnotetext{
${ }^{6}$ For twentieth century examples, see the short-lived punk fanzine Manchester Rains (https://www.mdmarchive.co.uk/exhibition/467/fanzine:-manchesterrains) and the long running TV soap Coronation Street (1960-present) known for its depiction of a close-knit working class street in Salford (Greater Manchester). The shows' visual iconography-cobbled streets, rainy weather, and a warm pub-represent a static nostalgic version of the city, which today is at odds with Manchester's gentrified and more cosmopolitan identity (Milestone, 2008).
} 
it was an idea that would not go away. For while the city continued to prosper, it was in industrialists, civic leaders, and ultimately the workers' own interests to perpetuate the idea that Manchester and its surrounding towns provided the perfect place for industrial growth. Whether that was the proximity of reliable coalfields, easy access to global markets via the Manchester Ship Canal, or the purportedly exceptional qualities of its damp climate.

\section{From Marketing to Pop Culture, How Climate Becomes Embedded in Cultural Identity}

In the previous section, we have seen how initial academic interest in the climate of Manchester during the nineteenth and early-twentieth century, particularly in relation to the region's rainfall and humidity, was utilized by both social reformers and industrialists. However, in the mid-twentieth century, once heavy industry began to decline and the economic focus of the city and region shifted, the reputation for being a wet and damp place became a hindrance to civic authorities trying to regenerate the city region. In the early 1960s, the city council's Information Officer promoted "anti-rain propaganda" to combat the idea that Manchester's weather makes it a bad place to visit, do business or indeed live (The Guardian, 1961). Despite these attempts, as the region entered a long period of economic decline, references to the city's inclement weather became increasingly pejorative in tone. ${ }^{7}$ Even as recently as 1993, as part of Manchester's unsuccessful bid to host the 2000 Olympics, television meteorologist Suzanne Charlton was tasked with demonstrating to the International Olympic Committee that the city was not particularly rainy, especially during the crucial summer months (Rampton, 1993).

By the mid-1990s, as city officials and businesses sought to rebrand the city, a more positive association between Manchester and its rainy reputation returned. As the city underwent postindustrial regeneration centered on shopping, tourism and leisure activities, businesses and civic leaders capitalized on the cache of recent Mancunian cultural exports, including bands such as Joy Division and the Smiths and the acid house music scene centered on the Haçienda nightclub (Degen, 2008; Carter, 2013). Marketing executives and the wider population drew upon the centrality of both the weather and the city's industrial heritage in popular cultural outputs. This shift was typified by the revival of the nickname "Cottonpolis" and other iconography connected to the city's past, in particular the worker bee, which had originally been adopted by industrialists as part of a savvy rebranding of the cities coat of arms back in 1842 (Beswick, 2020). ${ }^{8}$

\footnotetext{
${ }^{7}$ For just two examples among many from the popular press that refer to Manchester's rainy climate and connect it to the city's fortunes, see Mather, 1969; Heren, 1983.

${ }^{8}$ An epithet for Manchester used since at least the early 1850s; the fortunes of the nickname Cottonopolis can be seen by plotting the frequency of the word's use in the British English corpus of books using the Google NGram Viewer (https:// books.google.com/ngrams). This shows that while the nickname never returned to the level of popularity found in the late nineteenth and early twentieth century,
}

Across many sub-cultures and youth cultures that had proliferated in Manchester and the north-west of England during the 1980s, there were myriad references to the city as a rainy place. Perhaps most evocatively and famously captured in the lyrics of the Smiths' song "William, it was really nothing":?
The rain falls hard on a humdrum town
this town has dragged you down
oh the rain falls hard on a humdrum town
this town has dragged you down (Marr and Morrissey, 1984).

In addition to music, fashion was central to many of the emergent sub-cultures in the city, and here, once again, the climate played a prominent role. Drawing on street and football culture, popular fashion styles emerged that incorporated practical outerwear, for example cagoules (Figure 3) - a specific type of raincoat-that became a fashion-must for those in the late 1980s rave scene (Wiseman-Trowse, 2008). ${ }^{10}$ Echoing the narrative of nineteenth century industrialists who said that the weather was a key factor in the city's success, late twentiethcentury civic leaders and ambassadors often evoked Manchester's weather when speaking about the city's regeneration and cultural successes. ${ }^{11}$ While the rainfall statistics for the city region show relatively little change during the 150 years since Manchester's first boom, by the time the city was undergoing its post-industrial renaissance as a city destination, the orientation and relationship to its rainy reputation was completely transformed. As the Mancunian and author, Dave Haslam, summarizes:

\begin{abstract}
"In all the photographs of the city center from the 1970s, the sky is overcast and gray, but on pictures of the new and improved Manchester the sun is shining. Miraculously, even Manchester's infamous bad weather has been regenerated (Haslam, 1999, p. 250)."
\end{abstract}

As City Council executives sought investment and poured their marketing spin onto the city's skyline, Manchester began to shake its desultory reputation as a gray and wet place. In doing so, the rainy city moniker slowly shed its pejorative overtones. Beyond the boardroom, via the spontaneity of local sub-cultures, music scenes and the changing demographics of its working-class communities, Manchester's association with rain and gray once again became a badge of pride (e.g., Figure 4). ${ }^{12}$

following a period of sharp decline and stagnation its use increased again from the mid-1970s onwards.

${ }^{9}$ For more on the relationship between Manchester, its weather and the Smiths' lyrics, see Pordzik, 2007; Klein, 2018.

${ }^{10}$ For an introduction to the youth culture music scenes associated with Manchester in the period, dubbed "Madchester" by the popular press, see Wiseman-Trowse, 2008; Milestone, 2019.

${ }^{11}$ For just two examples from the period that incorporate the cities weather into coverage of the cultural and physical regeneration of the city, see Schlosser, 1998; Mead, 2007.

${ }^{12}$ For an example in which the DJ and author Dave Haslam reflects on the corporate appropriation of Manchester's youth and working class culture, see Adams, 2002. For a large collection of artefacts, memorabilia and other material and print culture from Manchester's music scenes see: The Manchester District Music Archive, Available online at: https://www.mdmarchive.co.uk/ (last accessed October 22, 2021) 
The history of place, both the physical environment and its social manifestations connect directly to the social identity of its citizens. In urban settings, too often we consider Homo sapiens as completely disconnected from the natural world (Ruddick, 2015; Steele, 2020). However, in this article, we have been reminded of how serendipitous past decisions, and vague, mythic, or even folkloric associations between places, people and climate come into existence and persist even in our muchaltered twenty-first century urban landscapes. In a relatively short space of time, Manchester's rainy reputation shifted from a pejorative moniker associated with the city's bleak post-industrial landscape to a central component of the city's narrative, both at the corporate and community-levels. Today, independent of climatological data, Manchester's proud identity as a rainy place abounds, from popular podcasts to the titles of sports clubs and leagues (Figure 4). ${ }^{13} \mathrm{~A}$ better understanding of this kind of regional identity, social association and local history should be a central component of climate change communication when targeting specific communities. By taking account of popular local perceptions of the environment and climate we may be able to design outreach activities which are better able to cut through political and social barriers to reach a wider cross-section of a community. Particularly when it comes to enacting behavioral change, a "context-specific" approach (IPCC, 2014), which incorporates salient local identities can help to avoid climate "reductionism" (Hulme, 2011b) and empower communities to undertake tangible positive actions. For example, incorporating the case study of Manchester presented here into the design of climate communication activities could result in projects that build trust by focussing on the citizens rich affinity with rain. While at the same time, also improving buy-in and imparting urgency, by centring conversations on how precipitation in the region is going to change over the coming decades.

Thus far, what I have outlined has been a corporate local history, in that it has dealt with the history of Manchester's institutions and communities at a distance. Exploring more granular everyday personal-accounts and relating them to macro trends is more challenging for historians. Over the distance of time, it is often difficult to discern how individuals have associated and related to their environment and climate. However, through the artistry of local dialects, phrases and jokes, and the relational artifacts they contain, we can get a glimpse of the central role that weather and climate have played in past communities (Macfarlane, 2015). In the case of Manchester, rain has loomed large in the jokes of generations of comedians from the city and its satellite towns. From the music hall anarchy of Frank Randle (1901-1957) to the hyper-regional songs of Chris Sievey's (1955-2010) Frank Sidebottom, dialect and language, the regional landscape, and its climate have long been combined for comic effect (Lee, 2004). ${ }^{14}$ Continuing in this tradition, in his

\footnotetext{
${ }^{13}$ See: "Guy Garvey's Rainy City", BBC Radio 6 Music, July 8, 2021 [https://www. bbc.co.uk/programmes/b00v7sjc]; the Rainy City Roller Derby League (FIG 4); and Lancashire County Cricket Club’s limited over team Lancashire Lightning [https:// cricket.lancashirecricket.co.uk/club/history-of-the-club/].

${ }^{14}$ For more on the career of Chris Sievey and his comic creation Frank Sidebottom see: Being Frank: The Chris Sievey Story, directed by Sullivan (2018).
}

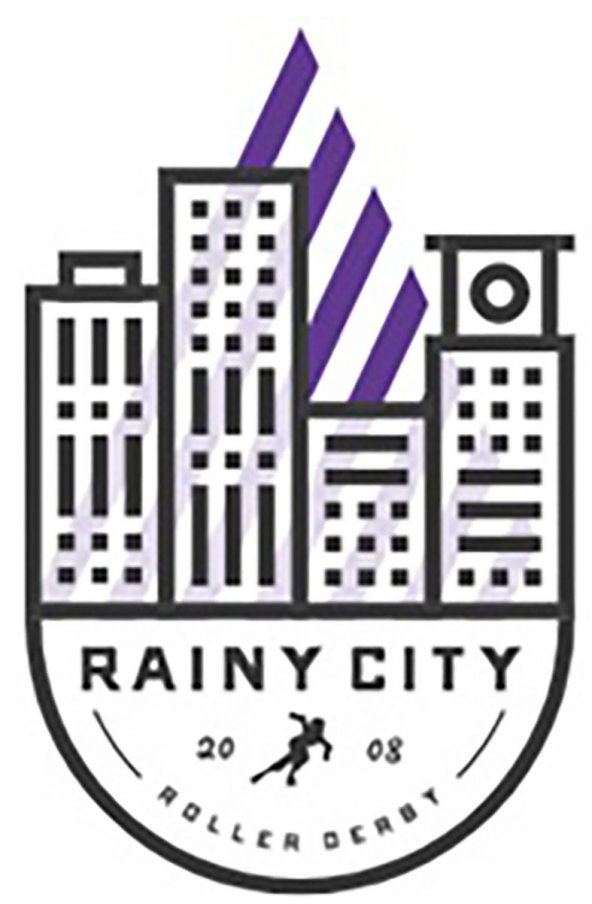

FIGURE 4 | The badge of Manchester's roller derby league. Source: https:// rainycityrollerderby.com/.

1999 live show, the award-winning Lancastrian comedian Peter Kay incorporated the weather and the rich regional language associated with it into the working-class scenes he brought to life on stage. For example, in one sketch about school dinner-ladies in his home town of Bolton:

\begin{abstract}
"They used to go mad if it rained as well... you'd be playing out and they'd have these... they'd have fits, they couldn't believe it...they'd be like...they'd get all hysterical... They'd see yer, and they'd be stood about hundred yards apart, and they could feel it coming, rain. They could feel it coming. They'd be like eyeing each other up and down... They were looking like that and they could sense it...like that...smell it, they could smell it! They could smell the rain! One big splodge like that..."its spitting, its spitting, its spitting! Everybody in! Everybody inside its spitting! Janice, Barbara-get the kids, get em inside, its spitting! Get inside, up the playground childrensave yerselves! Its spitting!”... Its like the beginning of Saving Private Ryan. ${ }^{15}$
\end{abstract}

In using regional dialect and idioms related to the inclement weather in a variety performance setting, Kay's routine drew on long-standing traditions of northern comedy, centring the apparently peculiar regional affinity with bad weather. Kay's audience immediately recognized the specific language he used when speaking about the weather. Later in the same show, he referred to, "that fine rain that soaks you through", without

\footnotetext{
${ }^{15}$ Peter Kay, Live at the Top of the Tower, directed by Mortimer (2000).
} 
articulating in more detail what he meant. Reflecting the show's popularity, the phrase which was already well-known among working-class northerners saw a subsequent uptick in use across the country. ${ }^{16}$ The phrase is just one example of modern parlance, which builds on the large canon of more traditional regional dialect and phrases used by Brits to describe drizzle. ${ }^{17}$

Through introducing these examples of Mancunian comedians and the role rain plays in their humor, I am not attempting to argue that such comedic focus on the weather is exceptional. These humourists do not talk about rain because they are from Manchester. Rather, how they talk about the rain is because they are from Manchester. The rains centrality in their jokes, their attitudinal relationship to the local climate and the dialect they use is specific to their locale and the traditions of stand-up comedy they are situated within. Some anthropologists have attempted to explain the English obsession with the weather as more about codified social norms, than the specific meteorological conditions individuals are encountering (Fox, 2005). Yet such attempts to reduce weather-talk to mere social convention overlook the specificity of different regional communities' knowledge and the rich history and diversity of weather-lore in the UK (e.g., Inwards, 1869). Further, by exceptionalizing the British (or even English) relationship with the weather, we disconnect British climate-society relationships from similar trends and patterns across other regions of the world. More global perspectives (e.g., Strauss and Orlove, 2003) remind us, that whether urban or rural, post-industrial or agrarian, climate and environment play an integral role in identity in all human societies.

\section{DISCUSSION}

Faced with the scale of the myriad challenges presented by the climate emergency and our continued inaction, it would be easy to dismiss the examples introduced in this article as interesting but trivial. However, as the development of a range of academic literature on ethnometeorology and other folk environmental knowledge has demonstrated, whether urban or rural (Janković and Barboza, 2009), local cultures have repeatedly been shown to be repositories of important climatological knowledge. From analysis of historical records (Endfield and Veale, 2019), language and toponymy (Jones, 2016), through to studies such as this one which consider the historical roots of contemporary perceptions of climate,

\footnotetext{
${ }^{16}$ In addition to its DVD release, Live at the Top of the Tower aired on Channel 5 television on December 26, 2001, receiving an audience of just under 1 million (Broadcasters' Audience Research Board Online); by 2011 it was reported that Kay was the first comedian to have sold over 10 million DVDs (BBC News, 2011). Reflecting the popularity of his show, the British English corpus on Google's NGram Viewer and the newspaper database Lexis Nexis show upticks post-2000 in the frequency of the phrase "fine rain" and "fine rain that soaks you" respectively. For some examples from a range of different media that show the influence of Kay's use of the phrase, see Pearson, 2007; Chivers, 2014; McMullin, 2017. Further a range of references to the phrase, connecting it with Kay can be found across social media, from popular memes to discussions on online community forums such as Reddit and Quora.

${ }^{17}$ For a glossary of regional weather terms, see Macfarlane, 2015.
}

these approaches illuminate new and important climatesociety relationships. Furthermore, such investigations need not focus purely on extracting empirical information of use to contemporary science. For as well as being vehicles for intergenerational empirical information, such folkloric traditions form the very fibers with which communities are weaved; enmeshing their histories, their traumas, and their very environments into the language and narratives that sustain them.

By analyzing how the climate we live in is internalized by citizens as part of their identity, we can build a better picture of the different ways that diverse communities might conceive of their climate changing in the future. Bringing historical case-studies from diverse communities into conversation with other climate-society research, exploring aspects such as memory and weather (Hall and Endfield, 2016), can help us to bring new communities into climate adaptation discussions. Whether the positive association between traditional belief systems and land-stewardship, or a more self-depreciating pride in a denuded or polluted industrial landscape, understanding how people form and perform emotional attachment with their physical environment could be a useful tool for those wishing to develop more participatory pathways for climate adaptation. ${ }^{18}$ Future work in this vein might explore how such attachments and identities have informed indifference or inaction regarding the threat posed by climate change; and how we might better harness the affection for regional weather and local environments to promote individual and collective behavior change. In this light, the regular quip from my climate skeptic uncles-"I'm looking forward to Manchester being a bit hotter"-could become the starting point for more constructive climate engagements. By centring the familiar and discussing climate change and adaptation in the language and framework most familiar to a specific community group we can also get beyond confrontational impasses, which are often focused on the geopolitical.

Zooming out, are there any generalized essences that climate change scholars, science communicators and climate activists can take from this essay? Perhaps the most important is the centrality and importance of narrative and storytelling. For as Martha Nussbaum argues in Love's Knowledge, storytelling is the way in which emotions are told, expressed, and understood most successfully (Nussbaum, 1992). In further developing this work from the academic to the active, we must be imaginative with the narratives we adopt and explore. We must not be limited by the stories we already know, for these already have a beginning, a middle and an end. Our aim is that the stories of the communities we work with continue on long into the future, despite the climate adaptation challenges they may face. To achieve this, we must co-create narratives that

\footnotetext{
${ }^{18}$ For one practical example of how such participatory interventions can be deployed, see the Let's Talk about the Weather event, and the wider Emotional Weather Bureau work of artist and curator Aidan Moesby. Available online at: https://aidanmoesby.co.uk/panels-talks-events/weather-talk/ (last accessed November 2, 2021).
} 
envelope community identity and individual differences into a positive pathway for climate adaptation. In The Life of Lines the anthropologist Tim Ingold says that "[f] ootprints are individual; paths are social". In connecting his own anthropology of lines to weather, Ingold shows that without narrative form, climate data is too inchoate and instructive to connect with most individuals (Ingold, 2015). While climate communicators may have known this for decades, too often the narratives we have focused on have been too largescale, or too distant in the future to hit home with communities whose attention we are vying for. We must take heed from authors such as Ingold and Robert Macfarlane and remember that the narratives we use and create must also be personal and connected to place.

More concretely, I hope that the case study outlined and the reflective process I undertook in writing this piece can encourage others to rethink the design of their climate communication activities. Building on the historical case study presented here, I am already imagining community activities that use future climate predictions for the city region to playfully explore how Manchester's already climatologically erroneous association with rain might develop in the coming decades and centuries. Further research and associated practical interventions, particularly in urban settings, must also expand to develop a better understanding of how routes of migration and diaspora networks effect both perceptions of climate and adaptive responses. While it is clear that the climate emergency requires vast structural and systemic changes, and as academics we should continue to empower communities to pressure governments and corporations, I believe that ground-up interventions, which center and value community knowledge of climate are also crucial. By asking Mancunians to reflect on their relationship with the rain and how they hope this will look in the future, we can utilize familiar language and narrative forms for a range of purposes, from processing climate anxiety and grief (Cunsolo

\section{REFERENCES}

Adams, T. (2002). May the North be With You: While London Stumbles from Crisis to Crisis, Manchester, Liverpool and Tyneside Finally Believe They Have Something to Write Home About. Is This the New North-South Divide? The Observer. Available online at: https://www.theguardian.com/society/2002/jul/ 28/communities.observerreview (Accessed October 22, 2021).

Adams, T. E., Holman Jones, S. L., and Ellis, C. (2015). Autoethnography. Oxford: Oxford University Press.

Adamson, G. C. D., Hannaford, M. J., and Rohland, E. J. (2018). Re-thinking the present: the role of a historical focus in climate change adaptation research. Glob. Environ. Change 48, 195-205. doi: 10.1016/j.gloenvcha.2017.12.003

Anandaraja, N., Rathakrishnan, T., Ramasubramanian, M., Saravanan, P., and Suganthi, N. S. (2008). Indigenous Weather and Forecast Practices of Coimbatore District Farmers. IJTK. Available online at: http://nopr.niscair.res.in/handle/ $123456789 / 2399$

Barnes, J., and Dove, M. R. (eds.). (2015). Climate Cultures: Anthropological Perspectives on Climate Change. New Haven: Yale University Press. doi: 10.12987/yale/9780300198812.001.0001

Barth, M., Masson, T., Fritsche, I., Fielding, K., and Smith, J. R. (2021). Collective Responses to Global Challenges: The Social Psychology of pro-Environmental Action. Journal of Environmental Psychology 74, doi: 10.1016/j.jenvp.2021.101562 et al., 2020) to overcoming psychological barriers to climate related behavioral change (Gifford, 2011).

The case study of Manchester shows us that such tactics and associations need not focus on esoteric, highbrow, or romanticized concepts. When stripped back to its bare bones, this example reminds us that our approach to talking about climate within communities must be rooted in the traditions familiar to that locale. For Mancunians, stereotype, class identity, self-depreciating humor and stubbornness are just some of the touchstones that feel familiar, and so, in this context, are narrative tools that might help in furthering participatory dialogue on climate and climate adaptation. In the 1946 Weather article that I introduced earlier, the author asked "[d]o Mancunians encourage the fiction that their city suffers from a peculiarly wet climate?" (Hawke, 1946). Well, I think whether we are talking about Victorian industrialists, posturing alternative musicians, or contemporary PR brochures the answer is an overwhelming yes. Yet, as I have argued, histories of popular science and science communication studies too often ignore such cultural dimensions. The fact that citizens actively encourage fictions about their climate has important implications for how we engage with diverse communities in relation to climate change, mitigation, and adaptation.

\section{DATA AVAILABILITY STATEMENT}

The original contributions presented in the study are included in the article/supplementary material, further inquiries can be directed to the corresponding author.

\section{AUTHOR CONTRIBUTIONS}

All research, work, and writing was undertaken by $\mathrm{AH}$.
Bayard, F. C. (1898). Q. J. $\quad$ R. Meteorol. Soc. 24, 261-261. doi: 10.1002/qj.49702410806

BBC News (2011). Peter Kay is the First Comedian to Sell 10 Million DVDs. Available online at: https://www.bbc.co.uk/news/newsbeat- 16158702 (Accessed January 26, 2022).

Beswick, A. (2020). The Story Behind the Manchester Bee - and Why It's Used Everywhere in the City. Available online at: https://www.visitmanchester.com/ ideas- and-inspiration/blog/read/2020/03/the-story-behind-the-manchesterbee-and-why-its-used-everywhere-in-the-city-b1121 (accessed October 22, 2021).

Carter, D. (2013). Urban regeneration, digital development strategies and the knowledge economy: Manchester case study. J. Knowledge Econ. 4, 169-189. doi: $10.1007 / \mathrm{s} 13132-012-0086-7$

Carvalho, A. (2007). Ideological cultures and media discourses on scientific knowledge: re-reading news on climate change. Public Understand. Sci. 16, 223-243. doi: 10.1177/0963662506066775

Chivers, T. (2014). Weather Watch. The Daily Telegraph, p. 43.

Craddock, J. M. (1976). Annual Rainfall in England since 1725. Q. J. R. Meteorol. Soc. 102, 823-840. doi: 10.1002/qj.49710243412

Cunsolo, A., Harper, S. L., Minor, K., Hayes, K., Williams, K. G., and Howard, C. (2020). Ecological grief and anxiety: the start of a healthy response to climate change? Lancet Planet. Health 4, e261-e263. doi: 10.1016/S2542-5196(20)30144-3 
Debrabant, M. (2010). Smoke or no smoke? Questions of perspective in north and south. Cahiers Victoriens et Édouardiens 71, 75-88. doi: 10.4000/cve.2828

Degen, M. M. (2008). Sensing Cities: Regenerating Public Life in Barcelona and Manchester. London: Routledge. doi: 10.4324/9780203895511

Elsdon-Baker, F., and Lightman, B. (2020). Identity in a Secular Age: Science, Religion, and Public Perception. Pittsburgh, PA: University of Pittsburgh Press. doi: $10.2307 / j . c t v 1595 n 98$

Endfield, G., and Veale, L. (2019). "Localising and historicising climate change: extreme weather histories in the united kingdom," in Climate and Culture: Multidisciplinary Perspectives on a Warming World, eds A. Arnall, G. Feola, and H. Geoghegan (Cambridge: Cambridge University Press), 190-216. doi: $10.1017 / 9781108505284.010$

Fleming, J. R. (2015). Weather and climate as shape-shifting nouns: gordian knots of understanding and prevision. History Meteorol. 7, 13.

Fleming, J. R., and Jankovic, V. (2011). Introduction: revisiting Klima. Osiris 26, 1-15. doi: $10.1086 / 661262$

Fox, K. (2005). Watching the English: The Hidden Rules of English Behaviour. London: Hachette.

Gifford, R. (2011). The dragons of inaction: psychological barriers that limit climate change mitigation and adaptation. Am. Psychol. 66, 290-302. doi: $10.1037 / \mathrm{a} 0023566$

Golinski, J. (2010). British Weather and the Climate of Enlightenment. Chicago, IL: University of Chicago Press.

Green, J. F. (2020). Less talk, more walk: why climate change demands activism in the academy. Daedalus 149, 151-162. doi: 10.1162/daed_a 01824

Hall, A. (2015). Geographers, stats-men and sages: approaches to climatology in Britain post-1945. History Meteorol. 7, 12.

Hall, A., and Endfield, G. (2016). "Snow scenes": exploring the role of memory and place in commemorating extreme winters. Weather Clim. Soc. 8, 5-19. doi: 10.1175/WCAS-D-15-0028.1

Haslam, D. (1999). Manchester, England: The Story of the Pop Cult City. London: Fourth Estate.

Hawke, E. L. (1946). The Manchester myth. Weather 1, 81-82. doi: 10.1002/j.1477-8696.1946.tb00039.x

Heren, L. (1983). Urban Rides 4: Manchester. London News.

Holzhausen, J., and Grecksch, K. (2021). Historic narratives, myths and human behavior in times of climate change: a review from Northern Europe's Coastlands. WIREs Climate Change 12, 5. doi: 10.1002/wcc. 723

Hulme, M. (2011a). Meet the humanities. Nat. Clim. Change 1, 177-179. doi: $10.1038 /$ nclimate 1150

Hulme, M. (2011b). Reducing the future to climate: a story of climate determinism and reductionism. Osiris 26, 245-266. doi: 10.1086/661274

Hulme, M. (2012). "Telling a different tale": literary, historical and meteorological readings of a Norfolk Heatwave. Clim. Change 113, 5-21. doi: 10.1007/s10584-012-0400-1

Ingold, T. (2011). Being Alive: Essays on Movement, Knowledge and Description. London: Taylor and Francis.

Ingold, T. (2015). The Life of Lines. Oxford: Routledge. doi: $10.4324 / 9781315727240$

Inwards, R. (1869). Weather Lore. London: W. Tweedie.

IPCC (2014). "Climate change 2014: impacts, adaptation, and vulnerability. Part B: regional aspects," in Contribution of Working Group II to the Fifth Assessment Report of the Intergovernmental Panel on Climate Change, eds V. R. Barros, C. B. Field, D. J. Dokken, M. D. Mastrandrea, K. J. Mach, T. E. Bilir, M. Chatterjee, K. L. Ebi, Y. O. Estrada, R. C. Genova, B. Girma, E. S. Kissel, A. N. Levy, S. MacCracken, P. R. Mastrandrea, and L. L.White (Cambridge: Cambridge University Press), 688.

Janković, V., and Barboza, C. H. (2009). Weather, Local Knowledge and Everyday Life: Issues in Integrated Climate Studies. Rio de Janeiro: MAST.

Jewkes, J. (1930). The localisation of the cotton industry. Econ. History 2, 91-106. doi: 10.1093/ej/40.Supplement_1.91

Jones, R. (2016). Responding to modern flooding: old English place-names as a repository of traditional ecological knowledge. J. Ecol. Anthropol. 18, 1. doi: 10.5038/2162-4593.18.1.9

Klein, Y. (2018). Manchester: A City Written by The Smiths. Available online at: https://medium.com/@yessicaklein/manchester-a-city-written-bythe-smiths-b8b0c0ba117c (accessed October 31, 2021).
Köppen, W. P. (1881). Frequency and duration of rain. Q. J. R. Meteorol. Soc. 7, 194-198. doi: 10.1002/qj.4970073905

La Barre, W. (1942). Folk medicine and folk science. J. Am. Folklore 55, 197-203. doi: $10.2307 / 535861$

Lee, C. P. (2004). "The Lancashire Shaman: Frank Randle and Mancunian Films," in Because I Tell a Joke or Two: Comedy, Politics and Social Difference, ed S. Wagg (London: Routledge) 32-49.

Lefale, P. F. (2010). Ua 'afa Le Aso stormy weather today: traditional ecological knowledge of weather and climate. The Samoa experience. Clim. Change 100, 317-335. doi: 10.1007/s10584-009-9722-z

Macfarlane, R. (2015). Landmarks. London: Penguin.

Marr, J., and Morrissey, S. (1984). William, It Was Really Nothing. The Smiths. London: Rough Trade Records.

Mather, W. (1969). City Comes Clean to Disprove the Critics. London: The Times, 2 .

McMullin, K. (2017). Which Type of Rain Will Get You the Wettest?; Turns Out Out Peter Kay Was Right. Liverpool: ECHO. Available online at: https://www. liverpoolecho.co.uk/news/liverpool-news/type - rain-you-wettest-13141197

Mead, R. (2007). Manchester United. The New Yorker (New York, NY).

Milestone, K. (2008). Urban myths: popular culture, the city and identity. Sociol. Compass 2, 1165-1178. doi: 10.1111/j.1751-9020.2008.00128.x

Milestone, K. (2019). "Madchester," in Sounds and the City, Vol. 2, eds B. Lashua, S. Wagg, K. Spracklen, and M. Yavuz (Cham: Palgrave Macmillan), 303-319. doi: 10.1007/978-3-319-94081-6_15

Mortimer, M. (dir.) (2000). Live at the Top of the Tower. Phil McIntyre Promotions Ltd.

Mosley, S. (2016). Selling the smokeless city: advertising images and smoke abatement in urban-industrial Britain, circa 1840-1960. History Technol. 32, 201-211. doi: 10.1080/07341512.2016.1218956

Myrick, J. G., and Comfort, S. E. (2019). The pope, politics, and climate change: an experimental test of the influence of news about Pope Francis on American climate change attitudes and intentions. J. Religion Media Digit. Cult. 8, 226-245. doi: 10.1163/21659214-00802003

National Smoke Abatement Institution (1887). Air Pollution: A Series of Lectures, delivered in Manchester during the winter 1886-87. London: John Heywood.

Nerlich, B., Koteyko, N., and Brown, B. (2010). Theory and language of climate change communication. WIREs Clim. Change 1, 97-110. doi: 10.1002/wcc.2

Nussbaum, M. C. (1992). Love's Knowledge: Essays on Philosophy and Literature. Oxford: Oxford University Press.

Ogden, H. W. (1927). The geographical basis of the Lancashire cotton industry. J. Textile Instit. Trans. 18, 11. doi: 10.1080/19447022708661440

Orlove, B. S., Chiang, J. C. H., and Cane, M. A. (2000). Forecasting andean rainfall and crop yield from the influence of El Niño on Pleiades visibility. Nature 403 68-71. doi: $10.1038 / 47456$

Pauly, D. (1995). Anecdotes and the shifting baseline syndrome of fisheries. Trends Ecol. Evol. 10, 430. doi: 10.1016/S0169-5347(00)89171-5

Pearson, H. (2007). Grim Up North? Give over, It's Grand. Daily Mail, p. 67.

Pfister, C. (2010). The vulnerability of past societies to climatic variation: a new focus for historical climatology in the twenty-first century. Clim. Change 100, 25-31. doi: 10.1007/s10584-010-9829-2

Platt, H. L. (2002). “'The hardest worked river:' the Manchester floods and the industrialisation of nature, 1850-1880," in Cities and Catastrophes: Coping with Emergency in European History, eds G. Massard-Guilbard, H. L. Platt, and D. Schott (Frankfurt: Peter Lang) 163-181.

Pordzik, R. (2007). "Of Popular Spaces: Northern Heterotopias, Morrissey and the Manchester Britpop Scene," in Thinking Northern, ed C. Ehland (Leiden: Brill).

Rampton, J. (1993). Long Runners. The Independent, p. 101.

Reed, P. (2016). Acid Rain and the Rise of the Environmental Chemist in Nineteenth Century Britain: The Life and Work of Robert Angus Smith. London: Routledge. doi: $10.4324 / 9781315565507$

Reverby, S. M. (2012). Tuskegee's Truths: Rethinking the Tuskegee Syphilis Study. North Carolina, NC: UNC Press Books.

Ringer, D., Carothers, C., Donkersloot, R., Coleman, J., and Cullenberg, P. (2018). For generations to come? The privatization paradigm and shifting social baselines in Kodiak, Alaska's commercial fisheries. Mar. Policy 98, 97-103. doi: 10.1016/j.marpol.2018.09.009

Royer, M.-J. S. (2018). “'The ice shards are gone': traditional ecological knowledge of climate and culture among the Cree of the Eastern James Bay, Canada," in 
Cultural Histories, Memories and Extreme Weather, eds G. H. Endfield and L. Veale (London: Routledge), 133-153. doi: 10.4324/9781315461458-8

Ruddick, S. (2015). Situating the anthropocene: planetary urbanization and the anthropological machine. Urban Geogr. 36, 1113-1130. doi: 10.1080/02723638.2015.1071993

Schlosberg, D., and Collins, L. B. (2014). From environmental to climate justice: climate change and the discourse of environmental justice. WIREs Clim. Change 5, 359-374. doi: 10.1002/wcc.275

Schlosser, E. (1998). Saturday night at the hacienda. Atlantic Monthly 282, 22-34.

Scott, R. H. (1898). The Frequency Of Rainy Days In The British islands. Q. J. R. Meteorol. Soc. 24, 217-228. doi: 10.1002/qj.49702410801

Simis, M. J., Madden, H., Cacciatore, M. A., and Yeo, S. K. (2016). The lure of rationality: why does the deficit model persist in science communication? Public Understand. Sci. 25, 400-414. doi: 10.1177/0963662516629749

Smith, R. A. (1872). Air and Rain: The Beginnings of a Chemical Climatology. London: Longmans, Green and Co.

Steele, W. (2020). Planning Wild Cities: Human-Nature Relationships in the Urban Age. London: Routledge. doi: 10.4324/9781315688756

Strauss, S., and Orlove, B. S. (2003). Weather, Climate, Culture. Oxford: Berg.

Suldovsky, B. (2017). The Information Deficit Model and Climate Change Communication. Oxford: Oxford Research Encyclopedia of Climate Science. doi: 10.1093/acrefore/9780190228620.013.301

Sullivan, S. (2018). Being Frank: The Chris Sievey Story. Altitude Films.

The Guardian (1961). The Myth of Manchester: Not Really Rainy.

The National Smoke Abatement Institutions (1888). Nature 37, 356-58. doi: $10.1038 / 037356 \mathrm{a} 0$ van Horssen, J. (2016). A Town Called Asbestos: Environmental Contamination, Health, and Resilience in a Resource Community. Vancouver, BC: University of British Columbia Press.

Vernon, G. V. (1871). On the rainfall at Old Trafford, Manchester, and comparison with the average of twenty years and seventy-seven years. Proc. Literary Philos. Soc. Manchester 10, 199-202.

Wiseman-Trowse, N. (2008). Performing Class in British Popular Music. London: Palgrave Macmillan. doi: 10.1057/9780230594975

Conflict of Interest: The author declares that the research was conducted in the absence of any commercial or financial relationships that could be construed as a potential conflict of interest.

Publisher's Note: All claims expressed in this article are solely those of the authors and do not necessarily represent those of their affiliated organizations, or those of the publisher, the editors and the reviewers. Any product that may be evaluated in this article, or claim that may be made by its manufacturer, is not guaranteed or endorsed by the publisher.

Copyright $\odot 2022$ Hall. This is an open-access article distributed under the terms of the Creative Commons Attribution License (CC BY). The use, distribution or reproduction in other forums is permitted, provided the original author(s) and the copyright owner(s) are credited and that the original publication in this journal is cited, in accordance with accepted academic practice. No use, distribution or reproduction is permitted which does not comply with these terms. 